\title{
Analysis of non-genetic and genetic influences underlying the growth of Kajli lambs
}

\author{
A. Ali ${ }^{1}$, K. Javed ${ }^{1 \#}$, I. Zahoor ${ }^{1}$ \& K.M. Anjum ${ }^{2}$ \\ ${ }^{1}$ Animal Breeding and Genetics, Department of Livestock Production, University of Veterinary and Animal Sciences \\ Lahore, Postal Code: 54000, Pakistan \\ ${ }^{2}$ Department of Wildlife \& Ecology, University of Veterinary and Animal Sciences Lahore, Pakistan \\ Study site: University of Veterinary and Animal Sciences Lahore 54000, Pakistan
}

(Submitted 22 November 2019; Accepted 25 June 2020; Published 2 October 2020)
Copyright resides with the authors in terms of the Creative Commons Attribution 4.0 South African Licence. See: http://creativecommons.org/licenses/by/4.0/za
Condition of use: The user may copy, distribute, transmit and adapt the work, but must recognise the authors and the South African Journal of Animal Science.

\begin{abstract}
Data on 2931 Kajli lambs, born from 2007 to 2018, were used to quantify environmental and genetic effects on growth performance of Kajli sheep. Traits considered for evaluation were birth weight (BWT), 120day adjusted weight (120DWT), 180-day adjusted weight (180DWT), 270-day adjusted weight (270DWT), and 365-day adjusted weight (365DWT). Fixed effects of year of birth, season of birth, sex, birth type, and dam age on these traits were evaluated using linear procedures of SAS, 9.1. Similarly, BWT, 120DWT, 180DWT, and 270DWT were used as fixed effects mixed model analyses. Variance components, heritability and breeding values were estimated by restricted maximum likelihood. The genetic trend for each trait was obtained by regression of the estimated breeding values (EBV) on year of birth. Analyses revealed substantial influence of birth year on all traits. Sex and birth type were the significant sources of variation for BWT and 120DWT. Season of birth did not influence birth weight meaningfully, but had a significant role in the expression of $120 \mathrm{DWT}, 180 \mathrm{DWT}$, and $270 \mathrm{DWT}$. Heritability estimates were generally low $(0.003 \pm 0.018$ to $0.099 \pm 0.067$ ) for all traits. With the exception of the genetic correlation of 180DWT and 365DWT, the genetic correlations between trait were strong and positive. Only 365DWT had a positive genetic trend. Although the heritability estimates for almost all weight traits were low, high and positive genetic correlations between BWT and other weight traits suggest that selection based on BWT would result in the improvement of other weight traits as a correlated response.
\end{abstract}

\footnotetext{
Keywords: bodyweight, breeding value, genetic correlation, sheep

\#Corresponding author: khalidjaved@uvas.edu.pk
}

\section{Introduction}

To feed more than 22 million population, especially with animal proteins, the development of costeffective small ruminant production is an important issue. To overcome the shortage of animal protein for human consumption, breeding programmes based on the selection of genetically superior individuals and their effective use in breeding would be a better option in the production of high yielding flocks and individuals (Khan et al., 2012).

The economically important traits in small ruminants (weight at various ages, growth rate, carcass characteristics) are subject to genetic and environmental influences. Enhancement in productivity of native breeds requires simultaneous improvement in the genetic makeup of flocks, while the provision of a suitable environment for optimal genetic expression of character is necessary. Therefore, effective breeding requires the selection of elite animals from flocks with better genetic worth. Growth, especially the pre-weaning growth rate in small ruminants, is influenced not only by the animal's own genetic makeup, but by environmental factors, that is, age of dam, birth weight, sex of lamb, and lambing season. So, to have maximum genetic progress through selection, it is critical to devise effective selection indices and reliable estimates of non-genetic and genetic parameters.

Sheep are raised chiefly for meat, and contribute meaningfully to the earnings of rural farmers (Wei et al., 2015). Pakistan holds 30.9 million head of sheep, which comprise 30 indigenous breeds (Afzal \& Naqvi, 2004; Anonymous, 2019). These include Balochi, Kachhi, Kaghani, Kajli, Kooka, Lohi, Sipli, and Thalli, all of 
these are coarse wool breeds. Kajli sheep are popular in the country because of their beauty and Kajli male lambs are preferred for sacrificial purposes at religious festivals such as Eid-ul-Azha (Qureshi et al., 2010). The breed is found mostly in the northern districts (Sargodha, Mianwali, Mandi Baha-ud-in, and Gujrat) of Punjab, Pakistan (Iqbal et al., 2014). Studies have been carried out to understand the morphometric measures (Iqbal et al., 2014), blood profile and physiological parameters (Saddiqi et al., 2011), genetic and non-genetic factors that govern the productive performance (Qureshi et al., 2010), and biodiversity of the Leptin (Qureshi et al., 2015) and Calpastatin genes (Khan et al., 2012; Suleman et al., 2012) in Kajli sheep. However, lamb production in Pakistan is shifting from free-range and semi-intensive systems of breeding and rearing to intensive systems, where the expenses of sheep enterprises are high. In such circumstances, without doubt, the growth traits require breeder's attention. Hence, this study was planned with the aim of obtaining an understanding of non-genetic and genetic factors that are related to the growth traits of Kajli sheep.

\section{Materials and Methods}

Data on growth records of 2931 Kajli sheep were collected from a state-owned livestock farm, Livestock Experiment Station Khushab (LES Khushab). The LES Khushab has held a population of Kajli sheep since the early 1980s. Since the introduction of Kajli sheep at the research centre, housing and feeding practices have remained comparable throughout the years. Mature male and female animals were maintained separately in open enclosures with proper shade areas to avoid the severity of the harsh climate. Generally, animals were allowed to graze for seven to eight hours every day, except during peak summer and winter days, when animals stayed inside enclosures. The daily grazing hours were further divided into five to six hours grazing on thorny bushes and leafy wild trees and two to three hours grazing on green fodder. When feed range was scarce, a limited amount of concentrate ration was provided to animals. The breeding was practised throughout the four seasons, though major breeding was practised in spring (February - April) and fall (August - October). Ewes that did not conceive during spring or autumn were exposed to rams in summer (May - July) and winter (November - January), respectively. Concentrate ration was also provided at the rate of $300 \mathrm{~g} /$ day to $500 \mathrm{~g} /$ day to breeding and lambing females for flushing and nourishment. Serving rams were also provided with concentrate supplements at the rate of $500-750 \mathrm{~g} / \mathrm{day}$ throughout the breeding seasons. New-born lambs were kept indoors till one month old, and were allowed to stay with their dams throughout the night and in the morning until dams went out for grazing in the fields. When lambs were a month old, they stayed with their dams for 24 hours and suckled freely. Post-weaning rearing of male and female lambs was practised in separate enclosures.

Information collected during the 12-year span (2007 - 2018) included pedigree, birth date, birth type, sex of lamb, and weight records at different ages. At LES Khushab, the pedigree, breeding and bodyweight records were maintained and preserved in a birth, breeding and liveweight register. The data were checked numerous times, and the records that did not fall within the range mean \pm SSD were considered outliers, and thus were not included in analyses. The pedigree structure is shown in Table 1. Traits analysed were birth weight (BWT), 120-day adjusted weight (120DWT), 180-day adjusted weight (180DWT), 270-day adjusted weight (270DWT), and 365-day adjusted weight (365DWT). Lambs were weighed once on the 25th of every month. Because the lambs varied in age at every weighing day, their weights were adjusted to standard ages following Akhtar et al. (2012).

Data were analysed to evaluate the effects of year of birth, season of birth, sex, birth type, dam age, BWT, 120DWT, 180DWT, and 270DWT through linear procedures of SAS 9.1 (SAS Insttute, Inc., Cary, North Carolina, USA). All fixed effects were assumed to be appropriate for each trait (Kuthu et al., 2013). The mathematical model used for the analysis was:

$$
Y_{i j k l m n}=\mu+\operatorname{sex}_{i}+\operatorname{tob}_{j}+\operatorname{aod}_{k}+\operatorname{sob}_{l}+y o b_{m}+e_{i j k l m n},
$$

where: $Y_{i j k l m n}=$ BWT, 120DWT, 180DWT, 270DWT or 365DWT;

$\mu=$ the population mean,

$\operatorname{sex}_{i}=$ the effect of the ith sex (male or female),

$t o b_{j}=$ the effect of the jth type of birth (single, twin or triplet),

$\operatorname{aod}_{k}=$ the effect of the kth age of dam (young $\leq 3.5$ years, mature $>3.5$ to 5.5 years or old $>5.5$ years),

$s o b_{l}=$ the effect of the Ith season of birth (February - April, May - July, August - October, or November - January),

$y o b_{m}=$ the effect of the mth year of birth $(2007,2008, \ldots 2018)$, and

$e_{i j k l m n}=$ the residual effect associated with $Y_{i j k l m n}$ assumed normally and independently distributed $\left(0, \sigma_{e}^{2}\right)$. 
Variance components were estimated with REML (Patterson \& Thompson, 1971) by fitting an individual animal model using WOMBAT software (Meyer, 2007). Pedigree information was traced as far back as possible, and was included in analyses to minimize bias due to selection or non-random mating. The convergence criteria (variance of function values -2 log likelihood) for genetic parameters were $1 \times 10^{-8}$. Single-trait analyses were used to estimate heritability. Only those fixed effects that were significant during the initial analysis were included in the model. Thus, the mathematical model for estimation of heritability was:

$$
Y_{i j k}=\mu+F_{i}+a_{j}+e_{i j k}
$$

where: $Y_{i j k}=\mathrm{WT}, 120 \mathrm{DWT}, 180 \mathrm{DWT}, 270 \mathrm{DWT}$ or 365DWT,

$\mu=$ the population mean,

$F_{i}=$ the ith subset of fixed effects that were significant in the initial analysis,

$a_{j}=$ the random additive genetic effect of jth animal with mean zero and variance $A \sigma_{a}^{2}$ where $A=$ the numerator relationship matrix based on pedigree, and

$e_{i j k}=$ the random error with mean zero and variance $\sigma_{e}^{2}$. the traits.

Corresponding bivariate analyses were carried out to estimate the covariances (correlations) between

\section{Results and Discussion}

Characteristics of the pedigree for animals used in this study are provided in Table 1. Only four lambs were sired by a ram whose identity was not known. Likewise, only 97 lambs had an unknown dam.

Table 1 Characteristics of the pedigree structure for Kajli sheep from the Livestock Experiment Station Khushab

Category Number of animals

Number of base animals with unknown parents

Number of animals with phenotypic records

Number of animals with unknown sire

Number of animals with unknown dam

Number of sires with progeny records

Number of dams with progeny records

Number of grandsires with progeny records

33

Number of granddams with progeny records

348

The mean, standard error (SE), minimum, maximum and heritability of all pre-yearling growth parameters of lambs are presented in Table 2. The mean \pm SE of birth weight, 120DWT, 180DWT, 270DWT, and 365DWT were $4.78 \pm 0.02,17.88 \pm 0.1,22.26 \pm 0.13,28.72 \pm 0.18$, and $32.65 \pm 0.22 \mathrm{~kg}$, respectively.

Analysis of variance (ANOVA) was performed to explore the effects of YOB, SOB, sex, birth type, dam age, BWT, 120DWT, 180DWT, and 270DWT on the growth traits. Analyses revealed significant $(P$ $\leq 0.05$ ) influences of birth year on all growth traits (Table 3). Despite being of similar weight at birth, lambs born in summer were generally lighter at the intermediate ages than lambs born in the other seasons. However, at 365 days of age lambs born in summer were similar in weight to those born in winter, spring and fall. Sex of lambs contributed significantly $(P \leq 0.05)$ to the weights at all ages except 270 days. Male lambs were heavier at birth and at 365 days old, while females performed comparatively $(P \leq 0.05)$ better than males at 120 and 180 days old (Table 4). Birth type $(P \leq 0.05)$ affected BWT and 120DWT. Single-born lambs were heavier $(P \leq 0.05)$ than twins and triplets at birth and 120DWT, with twins also being heavier than triplets at these ages. However, the triplet-born lambs were heavier at 270DWT and 365DWT than lambs that were born in smaller litters which may be a manifestation of compensatory growth. Age of dam also affected $(P \leq 0.05)$ BWT, but not weights recorded at the subsequent ages. 
Following Kuthu et al. (2013), effects of earlier in life weight on subsequent bodyweights were also examined as fixed effects to minimize their influence on weights at later ages. Later in life body weights adjusted for previously observed weights (Table 5) are properly interpreted as indicators of growth between the ages at which the weights were recorded. In general, lambs that were heavier at a younger age grew more rapidly to the next older age with the effects being diluted as the difference in ages increased. Thus, the effect of BWT on 120DWT was significant $(P \leq 0.05)$. The 120DWT weight had a significant influence on 180DWT, 270DWT and 365DWT. Lambs with high 270DWT had $(P \leq 0.05)$ higher 365DWT.

Table 2 Estimates of the overall mean, minimum, maximum and heritability for growth traits of Kajli sheep

\begin{tabular}{lccccc}
\hline Trait, kg & $\mathrm{N}$ & Mean \pm SE & Minimum & Maximum & heritability \\
\hline Birth weight & 2930 & $4.78 \pm 0.02$ & 1.5 & 7.4 & $0.058 \pm 0.037$ \\
120-day weight & 1868 & $17.88 \pm 0.10$ & 6.78 & 32.2 & $0.003 \pm 0.018$ \\
180-day weight & 1438 & $22.26 \pm 0.13$ & 7.77 & 39.6 & $0.087 \pm 0.047$ \\
270-day weight & 1056 & $28.72 \pm 0.18$ & 12 & 53.4 & $0.019 \pm 0.028$ \\
365-day weight & 820 & $32.65 \pm 0.22$ & 14 & 61.3 & $0.099 \pm 0.067$
\end{tabular}

$\mathrm{N}$ : number of records 
Table 3 Least squares mean \pm standard error for the effects of year and season of birth on birth weight, 120-, 180-, 270- and 365-day adjusted weights

\begin{tabular}{|c|c|c|c|c|c|c|c|c|c|c|}
\hline \multirow{2}{*}{ Effect } & \multicolumn{2}{|c|}{ Birth weight, kg } & \multicolumn{2}{|c|}{ 120-day weight, kg } & \multicolumn{2}{|c|}{ 180-day weight, kg } & \multicolumn{2}{|c|}{ 270-day weight, kg } & \multicolumn{2}{|c|}{ 365-day weight, kg } \\
\hline & $\mathrm{N}$ & Mean \pm SE & $\mathrm{N}$ & Mean \pm SE & $\mathrm{N}$ & Mean \pm SE & $\mathrm{N}$ & Mean \pm SE & $\mathrm{N}$ & Mean \pm SE \\
\hline \multicolumn{11}{|l|}{ Year of birth } \\
\hline 2007 & 62 & $4.13^{\mathrm{cd}} \pm 0.10$ & 23 & $15.77^{d} \pm 0.61$ & 23 & $20.97^{\text {ef }} \pm 0.87$ & 23 & $31.45^{\mathrm{cd}} \pm 1.31$ & 20 & $35.51^{\mathrm{cb}} \pm 1.50$ \\
\hline 2008 & 221 & $4.06^{\text {fde }} \pm 0.05$ & 111 & $14.70^{d} \pm 0.30$ & 102 & $19.65^{\dagger} \pm 0.43$ & 75 & $32.38^{\text {cde }} \pm 0.64$ & 69 & $33.05^{d} \pm 0.86$ \\
\hline 2009 & 233 & $4.06^{\text {cde }} \pm 0.04$ & 110 & $14.04^{d} \pm 0.25$ & 101 & $19.55^{\dagger} \pm 0.38$ & 65 & $29.08^{\mathrm{gh}} \pm 0.58$ & 49 & $34.69^{d} \pm 0.45$ \\
\hline 2010 & 240 & $3.34^{h} \pm 0.06$ & 131 & $14.70^{d} \pm 0.28$ & 113 & $20.45^{\dagger} \pm 0.35$ & 79 & $29.19^{h} \pm 0.47$ & 68 & $34.20^{\mathrm{ef}} \pm 0.46$ \\
\hline 2011 & 234 & $4.13^{\text {cde }} \pm 0.07$ & 145 & $16.50^{c} \pm 0.29$ & 123 & $20.90^{\text {de }} \pm 0.35$ & 108 & $29.45^{\mathrm{ef}} \pm 0.54$ & 101 & $33.50^{d} \pm 0.64$ \\
\hline 2012 & 289 & $4.31^{b c} \pm 0.04$ & 201 & $16.02^{c} \pm 0.29$ & 152 & $20.95^{\mathrm{de}} \pm 0.42$ & 133 & $30.02^{\text {def }} \pm 0.37$ & 121 & $33.50^{d} \pm 0.40$ \\
\hline 2013 & 314 & $4.22^{\mathrm{ef}} \pm 0.04$ & 221 & $17.25^{\mathrm{bc}} \pm 0.25$ & 177 & $20.80^{d} \pm 0.27$ & 159 & $27.61^{\text {gh }} \pm 0.36$ & 129 & $30.89^{f} \pm 0.52$ \\
\hline 2014 & 298 & $3.93^{9} \pm 0.05$ & 239 & $16.93^{c} \pm 0.29$ & 163 & $20.84^{\text {de }} \pm 0.37$ & 115 & $29.48^{\mathrm{fg}} \pm 0.49$ & 86 & $33.40^{\mathrm{de}} \pm 0.65$ \\
\hline 2015 & 232 & $4.09^{\mathrm{fg}} \pm 0.05$ & 171 & $18.09^{\mathrm{ab}} \pm 0.31$ & 133 & $21.61^{\mathrm{cd}} \pm 0.42$ & 114 & $31.41^{c} \pm 0.45$ & 98 & $36.12^{c} \pm 0.48$ \\
\hline 2016 & 427 & $4.31^{\text {cde }} \pm 0.03$ & 266 & $17.88^{\mathrm{ab}} \pm 0.25$ & 229 & $24.58^{b c} \pm 0.29$ & 145 & $33.51^{b} \pm 0.47$ & 72 & $38.48^{b} \pm 0.61$ \\
\hline 2017 & 259 & $4.86^{a} \pm 0.04$ & 162 & $18.17^{a} \pm 0.33$ & 119 & $23.68^{b} \pm 0.42$ & 40 & $36.57^{\mathrm{a}} \pm 1.22$ & 7 & $42.37^{\mathrm{a}} \pm 1.51$ \\
\hline 2018 & 121 & $4.69^{b} \pm 0.09$ & 88 & $19.12^{\mathrm{a}} \pm 0.50$ & 3 & $32.07^{a} \pm 0.87$ & & & & \\
\hline \multicolumn{11}{|c|}{ Season of birth } \\
\hline Spring & 1701 & $4.18^{a} \pm 0.01$ & 1031 & $16.42^{a} \pm 0.12$ & 807 & $21.91^{\mathrm{a}} \pm 0.14$ & 600 & $29.11^{b} \pm 0.19$ & 475 & $34.95^{\mathrm{a}} \pm 0.27$ \\
\hline Summer & 187 & $4.23^{\mathrm{a}} \pm 0.07$ & 132 & $15.75^{b} \pm 0.33$ & 115 & $20.94^{b} \pm 0.45$ & 79 & $29.86^{c} \pm 0.76$ & 60 & $35.67^{a} \pm 0.93$ \\
\hline Fall & 961 & $4.14^{\mathrm{a}} \pm 0.02$ & 651 & $16.32^{\mathrm{a}} \pm 0.18$ & 474 & $22.14^{\mathrm{a}} \pm 0.26$ & 351 & $31.84^{a} \pm 0.36$ & 267 & $35.28^{\mathrm{a}} \pm 0.41$ \\
\hline Winter & 81 & $4.16^{a} \pm 0.10$ & 54 & $17.91^{a} \pm 0.46$ & 42 & $23.03^{\mathrm{a}} \pm 0.90$ & 26 & $32.88^{\mathrm{a}} \pm 0.99$ & 18 & $34.36^{a} \pm 0.81$ \\
\hline
\end{tabular}

Spring: February, March and April, Summer: May, June and July, Fall, August, September and October, Winter: November, December, January 
Table 4 Least squares mean \pm standard error for the effects of sex, type of birth, and age of dam on birth weight, 120-, 180-, 270- and 365-day adjusted weights

\begin{tabular}{|c|c|c|c|c|c|c|c|c|c|c|}
\hline \multirow{2}{*}{ Effect } & \multicolumn{2}{|c|}{ Birth weight $(\mathrm{kg})$} & \multicolumn{2}{|c|}{ 120DWT (kg) } & \multicolumn{2}{|c|}{ 180DWT (kg) } & \multicolumn{2}{|c|}{ 270DWT (kg) } & \multicolumn{2}{|c|}{ 365DWT (kg) } \\
\hline & $\mathrm{N}$ & Mean \pm SE & $\mathrm{N}$ & Mean \pm SE & $\mathrm{N}$ & Mean \pm SE & $\mathrm{N}$ & Mean \pm SE & $\mathrm{N}$ & Mean \pm SE \\
\hline \multicolumn{11}{|l|}{ Sex } \\
\hline Male & 1512 & $4.29^{a} \pm 0.02$ & 512 & $15.63^{b} \pm 0.17$ & 186 & $21.68^{b} \pm 0.38$ & 77 & $30.98^{a} \pm 0.91$ & 25 & $36.80^{a} \pm 2.82$ \\
\hline Female & 1418 & $4.06^{b} \pm 0.02$ & 1356 & $17.57^{\mathrm{a}} \pm 0.11$ & 1252 & $22.34^{a} \pm 0.13$ & 979 & $30.86^{a} \pm 0.18$ & 795 & $33.33^{b} \pm 0.21$ \\
\hline \multicolumn{11}{|l|}{ Birth type } \\
\hline Single & 2112 & $5.08^{a} \pm 0.01$ & 1291 & $17.53^{\mathrm{a}} \pm 0.11$ & 1021 & $22.26^{a} \pm 0.15$ & 777 & $30.02^{a} \pm 0.21$ & 616 & $34.89^{a} \pm 0.25$ \\
\hline Twin & 792 & $4.11^{b} \pm 0.02$ & 557 & $16.50^{b} \pm 0.17$ & 406 & $22.11^{a} \pm 0.23$ & 272 & $30.62^{a} \pm 0.36$ & 197 & $35.60^{a} \pm 0.41$ \\
\hline Triplet & 26 & $3.34^{\mathrm{c}} \pm 0.11$ & 20 & $15.77^{c} \pm 0.85$ & 11 & $21.65^{\mathrm{a}} \pm 1.06$ & 7 & $31.94^{a} \pm 1.63$ & 7 & $34.71^{a} \pm 2.37$ \\
\hline \multicolumn{11}{|l|}{ Dam age } \\
\hline Young & 1304 & $4.11^{b} \pm 0.02$ & 841 & $16.55^{\mathrm{a}} \pm 0.14$ & 633 & $21.92^{\mathrm{a}} \pm 0.18$ & 473 & $30.57^{\mathrm{a}} \pm 0.26$ & 370 & $34.81^{a} \pm 0.32$ \\
\hline Mature & 1062 & $4.22^{\mathrm{a}} \pm 0.02$ & 661 & $16.72^{\mathrm{a}} \pm 0.16$ & 536 & $22.03^{\mathrm{a}} \pm 0.22$ & 383 & $31.15^{\mathrm{a}} \pm 0.32$ & 291 & $35.33^{a} \pm 0.38$ \\
\hline Old & 564 & $4.20^{\mathrm{a}} \pm 0.03$ & 366 & $16.52^{\mathrm{a}} \pm 0.22$ & 269 & $22.07^{\mathrm{a}} \pm 0.29$ & 200 & $31.04^{a} \pm 0.41$ & 159 & $35.05^{a} \pm 0.46$ \\
\hline
\end{tabular}


Table 5 Least squares mean \pm standard error for the effects of previous weight classes on 120-, 180-, 270- and 365-day adjusted weights

\begin{tabular}{|c|c|c|c|c|c|c|c|c|}
\hline \multirow{2}{*}{ Effect } & \multicolumn{2}{|c|}{ 120DWT (kg) } & \multicolumn{2}{|c|}{ 180DWT (kg) } & \multicolumn{2}{|c|}{ 270DWT (kg) } & \multicolumn{2}{|c|}{ 365DWT (kg) } \\
\hline & $\mathrm{N}$ & Mean \pm SE & $\mathrm{N}$ & Mean \pm SE & $\mathrm{N}$ & Mean \pm SE & $\mathrm{N}$ & Mean \pm SE \\
\hline \multicolumn{9}{|l|}{ Birth weight } \\
\hline$<4 \mathrm{~kg}$ & 180 & $14.47^{d} \pm 0.28$ & 145 & $21.59^{\mathrm{a}} \pm 0.34$ & 116 & $30.39^{b} \pm 0.47$ & 97 & $35.19^{a} \pm 0.54$ \\
\hline$>4$ to $5 \mathrm{~kg}$ & 451 & $16.17^{\mathrm{c}} \pm 0.17$ & 354 & $21.82^{\mathrm{a}} \pm 0.22$ & 252 & $30.43^{b} \pm 0.31$ & 194 & $34.31^{a} \pm 0.36$ \\
\hline$>5$ to $6 \mathrm{~kg}$ & 1011 & $17.15^{\mathrm{b}} \pm 0.12$ & 782 & $22.18^{\mathrm{a}} \pm 0.17$ & 586 & $30.87^{b} \pm 0.25$ & 459 & $35.35^{a} \pm 0.30$ \\
\hline$>6 \mathrm{~kg}$ & 226 & $18.61^{a} \pm 0.26$ & 158 & $22.43^{a} \pm 0.39$ & 103 & $32.00^{a} \pm 0.61$ & 71 & $35.40^{a} \pm 0.89$ \\
\hline \multicolumn{9}{|c|}{ Adjusted 120-day weight } \\
\hline$\leq 15 \mathrm{~kg}$ & & & 347 & $17.60^{\circ} \pm 0.16$ & 252 & $29.95^{C} \pm 0.27$ & 198 & $33.97^{C} \pm 0.36$ \\
\hline$>15$ to $\leq 20 \mathrm{~kg}$ & & & 653 & $21.94^{b} \pm 0.11$ & 491 & $30.78^{b} \pm 0.22$ & 386 & $35.00^{b} \pm 0.28$ \\
\hline$>20 \mathrm{~kg}$ & & & 438 & $26.48^{\mathrm{a}} \pm 0.17$ & 313 & $32.03^{a} \pm 0.33$ & 236 & $36.23^{a} \pm 0.43$ \\
\hline \multicolumn{9}{|c|}{ Adjusted 180-day weight } \\
\hline$\leq 20 \mathrm{~kg}$ & & & & & 335 & $27.13^{c} \pm 0.23$ & 266 & $34.23^{b} \pm 0.29$ \\
\hline 20 to $25 \mathrm{~kg}$ & & & & & 519 & $30.50^{b} \pm 0.19$ & 422 & $35.05^{\mathrm{a}} \pm 0.27$ \\
\hline$>25 \mathrm{~kg}$ & & & & & 202 & $35.14^{a} \pm 0.38$ & 132 & $35.92^{a} \pm 0.53$ \\
\hline \multicolumn{9}{|c|}{ Adjusted 270-day weight } \\
\hline$>25 \mathrm{~kg}$ & & & & & & & 231 & $31.18^{C} \pm 0.30$ \\
\hline$\geq 25$ to $30 \mathrm{~kg}$ & & & & & & & 364 & $34.68^{b} \pm 0.21$ \\
\hline$\geq 31 \mathrm{~kg}$ & & & & & & & 225 & $39.33^{a} \pm 0.36$ \\
\hline
\end{tabular}


Estimates from the bivariate analyses of genetic, environmental, phenotypic correlations among various bod weight traits and the corresponding estimates of heritability are presented in Table 6.Most genetic and phenotypic correlation estimates between the weight traits of Kajli lambs were strongly positive. However, a non-significant negative genetic correlation was observed between 180DWT and 365DWT. Estimates of phenotypic correlations for all traits were positive and of intermediate magnitude. Estimates of heritability under bivariate analysis were with two exceptions similar to the corresponding estimates from the univariate analyses.

Table 6 Estimates of correlation and heritability obtained from bivariate analyses of the various weight traits

\begin{tabular}{lcccccc}
\hline \multirow{2}{*}{ Trait 1 } & Trait 2 & \multicolumn{3}{c}{ Estimates of correlation } & \multicolumn{2}{c}{ Heritability estimates } \\
\cline { 3 - 7 } & & Genetic & Environmental & Phenotypic & Trait 1 & Trait 2 \\
\hline BWT & 120DWT & $1.00 \pm 0.21$ & $0.21 \pm 0.03$ & 0.24 & $0.08 \pm 0.04$ & $0.03 \pm 0.03$ \\
BWT & 180DWT & $0.66 \pm 0.40$ & $0.18 \pm 0.03$ & 0.21 & $0.03 \pm 0.03$ & $0.13 \pm 0.05$ \\
BWT & 270DWT & $1.00 \pm 0.24$ & $0.12 \pm 0.04$ & 0.20 & $0.09 \pm 0.05$ & $0.09 \pm 0.05$ \\
BWT & 365DWT & $0.85 \pm 0.83$ & $0.15 \pm 0.04$ & 0.17 & $0.02 \pm 0.04$ & $0.05 \pm 0.05$ \\
120DWT & 180DWT & $1.00 \pm 0.06$ & $0.82 \pm 0.01$ & 0.82 & $0.05 \pm 0.03$ & $0.16 \pm 0.05$ \\
120DWT & 270DWT & $0.89 \pm 0.32$ & $0.57 \pm 0.02$ & 0.58 & $0.02 \pm 0.03$ & $0.05 \pm 0.04$ \\
120DWT & 365DWT & $0.44 \pm 0.69$ & $0.45 \pm 0.03$ & 0.45 & $0.03 \pm 0.03$ & $0.04 \pm 0.04$ \\
180DWT & 270DWT & $0.97 \pm 0.28$ & $0.26 \pm 0.02$ & 0.30 & $0.40 \pm 0.02$ & $0.03 \pm 0.02$ \\
180DWT & 365DWT & $-0.33 \pm 0.78$ & $0.59 \pm 0.03$ & 0.54 & $0.06 \pm 0.05$ & $0.03 \pm 0.04$ \\
270DWT & 365DWT & $0.88 \pm 0.99$ & $0.24 \pm 0.03$ & 0.24 & $0.44 \pm 0.03$ & $0.01 \pm 0.02$ \\
& & & & & & \\
\hline BWT:Binyyyy
\end{tabular}

BWT: Birth weight, 120DWT: age adjusted 120-day weight, 180DWT: age adjusted 180-day weight, 270DWT: age adjusted 270-day weight, 365DWT: age adjusted 265-day weight

Genetic trends for various growth traits are depicted in Figure 8. Genetic trends for most of these traits except 365DWT oscillated around the X-axis, indicating little or no genetic gain over the last 12 years.

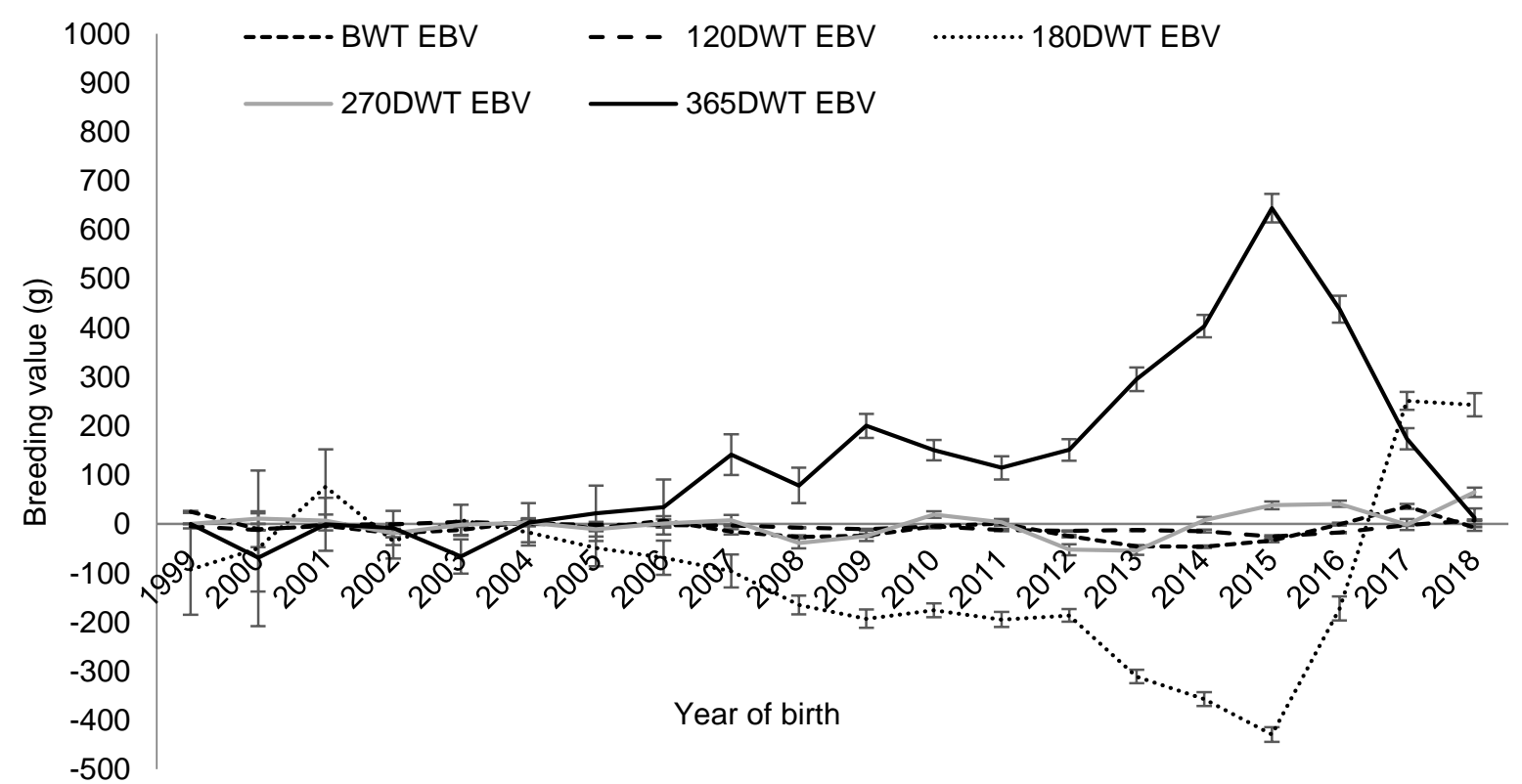

Figure 8 Genetic trends of bodyweight traits of Kajli sheep in different years 
Kajli lambs had noticeably higher growth ability at earlier ages (1 day to 120 days) compared with later ages. Their almost linear growth curve (Figure 1) is in agreement with the earlier reports (London \& Weniger, 1996; Gbangboche et al., 2006). Similar findings were reported by researchers in various breeds of Pakistan, namely Hissardale (Akhtar et al., 2001), Lohi (Babar et al., 2004), Mengali (Tariq et al., 2010), and in Buchi (Akhtar et al., 2012). Similarly, high growth rate during the weaning period was observed in Zandi (GhafouriKesbi et al., 2011) and Baluchi (Sarghale \& Arpanahi, 2014) breeds. The higher growth rate at an earlier age may be attributed to lower environmental stress on lambs because of maternal care and nourishment throughout the suckling period. However, because the maternal nourishment and care disappears after weaning, many stress factors play their role and lamb grows at a decreasing rate.

The significant effects on the performance of lambs born in various years may result from numerous causes including variation in agro-climatic conditions, nutrition, type and quality of fodder, incidence of disease, breeder's skill, selection strategy, herdsman's ability to supervise labour, and financial resources (Dass et al., 2004; Assan \& Makuza, 2005; Gbangboche et al., 2006; Vatankhah \& Salehi, 2010; Al-Bial \& Singh, 2012; Tohidi et al., 2017). In the present investigation, the SOB was divided into two major lambing seasons, that is, S1 (spring), S3 (autumn) (natural lambing seasons of small ruminants in Pakistan), and two minor (S2, summer; S4, winter) ones. Lambing season did not affect birth weight significantly, but was a significant source of variation for weight performances at later ages. The effect of SOB on lamb performance has been analysed by researchers (Fisher, 2004; Sušić et al., 2005; Benyi et al., 2006; Chniter et al., 2011; Akhtar et al., 2012; Javed et al., 2013). The differences owing to SOB can be related to one major factor, namely 'food', or the effects of availability, type of fresh pasture grass, and ambient environment (Petrovic et al., 2011). The results of the current study were comparable with those of an earlier report (Petrović et al., 2015), in which winter- and autumn-born lambs were lighter than those born in summer and spring. In most of these studies, SOB influenced the weight performances of lambs significantly.

The observed differences between male and female lambs in BWT and 365DWT were in agreement with the findings of most studies (Dass et al., 2004; Al-Bial \& Singh, 2012; Kesbi \& Tari, 2015; Lupi et al., 2015; Ghafouri-Kesbi \& Gholizadeh, 2017) that explained the hormonal disparity between the sexes. In female lambs, oestrogen limits skeleton growth, though testosterone regulates growth positively in males in the same way as growth hormone (Zung et al., 1999; Ghafouri-Kesbi \& Gholizadeh, 2017). However, the contrary results of weight at 120 and 180 days, when female lambs had higher weights, could be attributed to animal sales practice at LES Khushab, as most male lambs (comparatively healthier) are sold in the market because of their high demand as sacrificial animals and only a few male lambs are retained in the flock. So, significant differences in the numbers of records of male and female lambs might be the reason for not following the general trend of growth in male and female lambs.

In terms of birth type, single-born lambs were heavier than all multiples born at BWT and 120DWT, but triplets were superior at 270DWT. The 'phenomenon of compensatory growth' accounts for the higher weight of triplets at later ages (Kesbi \& Tari, 2015); Ghafouri-Kesbi \& Gholizadeh, 2017). This phenomenon states that there is a period of augmented growth after a spell of limited growth and development. Consequently, multiple-born lambs, which grow at a passive pace in the early days of life might express faster growth at later ages. Higher early age growth traits of single-born lambs conformed with reports from various studies that were conducted on sheep breeds of the same type that were maintained in different rearing systems, such as Hissardale (Akhtar et al., 2001), Baharet Merino (Dixit et al., 2001), Sabi (Matika et al., 2003), Western Range (Borg et al., 2009), Pulgia (Selvaggi et al., 2011), Lohi (Javed et al., 2013), Turcana lambs (Gavojdian, 2013), and Thalli (Hussain et al., 2014).

The significant influence of dam age on BWT was substantiated by previous studies (Babar et al., 2004; Baneh \& Hafezian, 2009; Eskandarinasab et al., 2010; Tariq et al., 2010; Selvaggi et al., 2011; Thiruvenkadan et al., 2011; Al-Bial \& Singh, 2012). However, dam age did not affect other weight traits significantly. The lambs of mature ewes were comparatively heavier at birth than those born to young ewes, because of the better uterine environment (mature size). The lack of differences in later age weight of lambs born to young and older dams may be because young or older dams usually produce less milk compared with middle-aged ones (3.5 - 5.5 years) (Ganai \& Pandey, 2000; Ghafouri-Kesbi \& Gholizadeh, 2017).

In the current analysis, significant $(P \leq 0.01)$ effects of BWT on 120DWT and of 120DWT on 180DWT, 270DWT and 365DWT were in agreement with Mohammadi et al. (2013) and Mandal et al. (2015), in which a significant correlation of BWT with weaning weight was reported. This significant association of early age performance with older age performance suggests that selection for weight at an early age would improve the weight of lambs at nine months and yearling ages (Caetano et al., 2013).

The estimate of heritability $\left(h^{2}\right)$ for BWT $(0.058 \pm 0.037)$ was in the reported range $(0.03-0.42)$ for Sangsari and Moroccan Timahdit breeds (El-Fadili et al., 2000; Miraei-Ashtiani et al., 2007). However, Javed 
et al. (2013) reported a slightly higher heritability estimate $(0.11 \pm 0.03)$ in the Lohi breed of Pakistan, which is still categorized as low. Besides, the estimates of heritability for 120DWT, 180DWT, 270DWT, and 365DWT were not in agreement with Menz, crossbred (Awassi $\times$ Menz) and Djalonke sheep (Gizaw \& Joshi, 2004; Bosso et al., 2007), but conformed with the range of 0.09 to 0.10 that was reported in Zandi sheep (Ghafouri-Kesbi et al., 2011).

Quantitative measures of additive genetic variance for weight at different ages revealed low values. The estimated heritability for 365DWT was slightly higher than observed earlier $(0.08 \pm 0.05)$ for the same trait in Kajli sheep (Qureshi et al., 2010). Low estimates of heritability in the current analysis agree with reported values of $0.07,0.09$ and 0.05 for birth weight, weight at 30 days old and weight at 90 days old, respectively, in Sardi sheep (Boujenane \& Diallo, 2017). Similarly, direct heritability estimates in D'man sheep for weight at birth, at 30 days old, and at 90 days old were $0.05 \pm 0.02,0.03 \pm 0.02$, and $0.08 \pm 0.03$, respectively (Boujenane et al., 2015). The findings of the present study are consistent with earlier results (Kruuk et al., 2000; Javed et al., 2013; Ghafouri-Kesbi \& Gholizadeh, 2017). Traits subject to large environmental effects that cannot be accounted for in the statistical analysis have low estimates of heritability and vice versa. Response to selection depends on additive genetic variance which was very low in the present study.

Low heritability estimates for growth traits that were observed in the current study may be because of improper performance recording, false pedigree information, and unintentional inbreeding. Rams were usually selected from the same flock in which they were born and were only occasionally introduced from field or other flocks. Moreover, poor quality of fodder and malnourishment of animals create high environmental variations, which result in a higher component of environmental variance to phenotypic variance and consequently lower estimates of heritability (Mandal et al., 2015; Gholizadeh \& Ghafouri-Kesbi, 2017). The estimates of genetic correlation for BWT-120DWT and 120DWT-180DWT in Kajli were higher than in most of the earlier studies. However, strong and positive genetic and phenotypic correlations among weight traits in Kajli agree with other estimates on breeds such as Shall (Mohammadi et al., 2013), Marwari (Singh et al., 2016), Harnali (Lalit et al., 2016), South African Merino (Nemutandani et al., 2018), Sardi (Boujenane \& Diallo, 2017), and Kermani sheep (Mokhtari et al., 2008), indicating the involvement of similar genes in the expression of the traits or the presence of linkage between these genes. Moreover, the strong genetic correlation of BWT with all other traits ranging from 1 to 0.6611 suggests that the selection for BWT in Kajli sheep would improve weight traits of later age as a correlated response.

Significantly positive genetic trend for 365DWT was observed in the current analysis. These results were supported by earlier findings (Mokhtari \& Rashidi, 2010; Snyman, 2012; Gholizadeh \& Ghafouri-Kesbi, 2015). The positive genetic trend for 365DWT could be attributable to reasonably large differences in EBV of the lambs. Moreover, the observed positive genetic trend for 365DWT proposed that Kajli sheep at LES Khushab might have been selected for yearling weight throughout these years. On the other hand, negligible genetic trends for birth weight, 120DWT, 180DWT and a negative genetic trend for 270DWT contraindicate selection for growth in the breed improvement programmes.

\section{Conclusion}

The results of the current analysis revealed low additive genetic variance and high phenotypic variance estimates for growth-related characters in Kajli sheep. However, the high and positive genetic correlation between birth weight and other weight traits suggests that selection based on birth weight would result in improvement of other weight traits as a correlated response. Furthermore, the findings of the present study suggested that in the past selection programmes were not focused and that little attention was paid to genetic worth.

\section{Acknowledgments}

The authors acknowledge the management and staff members at LES Khushab for providing us with data and all other resources for the completion of this study.

\section{Author's Contributions}

Concept, design, proof reading and submission: $\mathrm{KJ}, \mathrm{AA}$; data collection and analysis: $\mathrm{AA}, \mathrm{KJ}$; drafting of manuscript: AA, IZ, KMA.

\section{Conflict of Interest Declaration}

The authors declare there is no conflict of interest with any public, private organization or person for academic and financial interests related to the contents of this manuscript.

\section{References}

Afzal, M. \& Naqvi, A.N., 2004. Livestock genetic resources of Pakistan. Sci. Vision. 9, 1-14. 
Ahmad, Z., Yaqoob, M. \& Younas, M., 2001. The Lohi sheep: A meat breed of Pakistan review. Pakistan J. Agri. Sci. 38, 3-4.

Akhtar, M., Javed, K., Abdullah, M., Ahmad, N. \& Elzo, M.A., 2012. Environmental factors affecting preweaning growth traits of Buchi sheep in Pakistan. The JAPS. 22, 529-536.

Akhtar, P., Ahmad, Z., Mohiuddin, G., Ali, S. \& Javed, K., 2001. Environmental factors affecting preweaning growth traits of Hissardale sheep in Pakistan. Pakistan Vet. J. 21, 17-21.

Al-Bial, A.M. \& Singh, J., 2012. Factors effecting growth traits of Black Boni sheep. Tamilnadu J. Vet. Ani. Sci. 8, 194198.

Anonymous., 2019. Economic survey of Pakistan (2018-19). Economic Advisers Wing, Finance Division, Government of Pakistan, Islamabad.

Assan, N. \& Makuza, S.M., 2005. The effect of non-genetic factors on birth weight and weaning weight in three sheep breeds of Zimbabwe. Asian-Austral. J. Ani. Sci. 18, 151-157. https://doi.org/10.5713/ajas.2005.151

Babar, M.E., Ahmad, Z., Nadeem, A. \& Yaqoob, M., 2004. Environmental factors affecting birth weight in Lohi sheep. Pakistan Vet. J. 24, 5-8.

Baneh, H. \& Hafezian, S.H., 2009. Effects of environmental factors on growth traits in Ghezel sheep. African J. Biotech. 8, 2903-2907.

Benyi, K., Norris, D., Karbo, N. \& Kgomo, K.A., 2006. Effects of genetic and environmental factors on pre-weaning and post-weaning growth in West African crossbred sheep. Trop. Ani. Heal. Prod. 38, 547-554.

Borg, R.C., Notter, D.R. \& Kott, R.W., 2009. Phenotypic and genetic associations between lamb growth traits and adult ewe body weights in western range sheep. J. Ani. Sci. 87, 3506-3514. https://doi.org/10.2527/jas.2008-1622

Bosso, N.A., Cisse, M.F., Van der Waaij, E.H., Fall, A. \& van Arendonk, J.A.M., 2007. Genetic and phenotypic parameters of body weight in West African Dwarf goat and Djallonke sheep. Small Rumin. Res. 67, 271-278. https://doi.org/10.1016/j.smallrumres.2005.11.001

Boujenane, I., Chikhi, A., Ibnelbachyr, M. \& Mouh, F.Z., 2015. Estimation of genetic parameters and maternal effects for body weight at different ages in D'man sheep. Small Rumin. Res. 130, 27-35. https://doi.org/10.1016/j.smallrumres.2015.07.025

Boujenane, I. \& Diallo, I.T., 2017. Estimates of genetic parameters and genetic trends for pre-weaning growth traits in Sardi sheep. Small Rumin. Res. 146, 61-68. https://doi.org/10.1016/j.smallrumres.2016.12.002

Caetano, S.L., Savegnago, R.P., Boligon, A.A., Ramos, S.B., Chud, T.C.S., Lôbo, R.B. \& Munari, D.P., 2013. Estimates of genetic parameters for carcass, growth and reproductive traits in Nellore cattle. Livestock Sci. 155, 1-7. https://doi.org/10.1016/j.livsci.2013.04.004

Chniter, M., Hammadi, M., Khorchani, T., Krit, R., Lahsoumi, B., Sassi, M.B., Nowak, R. \& Hamouda, M.B., 2011. Phenotypic and seasonal factors influence birth weight, growth rate and lamb mortality in D'man sheep maintained under intensive management in Tunisian oases. Small Rumin. Res. 99, 166-170. https://doi.org/10.1016/j.smallrumres.2011.03.046

Dass, G., Singh, V.K. \& Ayub, M., 2004. Growth performance of Magra sheep under hot arid climate. Indian J. Ani. Sci. 74, 441-443.

Dixit, S.P., Dhillon, J.S. \& Singh, G., 2001. Genetic and non-genetic parameter estimates for growth traits of Bharat Merino lambs. Small Rumin. Res. 42, 101-104. https://doi.org/10.1016/S0921-4488(01)00231-0

El-Fadili, M., Michaux, C., Detilleux, J. \& Leroy, P.L., 2000. Genetic parameters for growth traits of the Moroccan Timahdit breed of sheep. Small Rumin. Res. 37, 203-208. https://doi.org/10.1016/S0921-4488(00)00126-7

Eskandarinasab, M., Ghafouri-Kesbi, F. \& Abbasi, M.A., 2010. Different models for evaluation of growth traits and Kleiber ratio in an experimental flock of Iranian fat-tailed Afshari sheep. J. Ani. Breed. Genet. 127, $26-33$. https://doi.org/10.1111/j.1439-0388.2008.00789.x

Fisher, M.W., 2004. A review of the welfare implications of out-of-season extensive lamb production systems in New Zealand. Livest. Prod. Sci. 85, 165-172. https://doi.org/10.1016/S0301-6226(03)00127-1

Ganai, T.A. \& Pandey, R.S., 2000. Factors influencing pre-and post-weaning survivability of exotic sheep. Indian J. Ani. Sci. 70, 316-318.

Gavojdian, D., 2013. Influence of production system, sex and litter size on growth rates in Turcana lambs. Scientific Papers Ani. Sci. Biotech. 46, 357-360.

Gbangboche, A.B., Youssao, A.K.I., Senou, M., Adamou-Ndiaye, M., Ahissou, A., Farnir, F., Michaux, C., Abiola, F.A. \& Leroy, P.L., 2006. Examination of non-genetic factors affecting the growth performance of djallonke sheep in soudanian zone at the Okpara breeding farm of Benin. Trop. Ani. Heal. Prod. 38, 55-64. https://doi.org/10.1007/s11250-006-4231-9

Ghafouri-Kesbi, F. \& Gholizadeh, M., 2017. Genetic and phenotypic aspects of growth rate and efficiency-related traits in sheep. Small Rumin. Res. 149, 181-187. https://doi.org/10.1016/j.smallrumres.2017.02.006

Ghafouri-Kesbi, F., Abbasi, M.A., Afraz, F., Babaei, M., Baneh, H. \& Arpanahi, R.A., 2011. Genetic analysis of growth rate and Kleiber ratio in Zandi sheep. Trop. Ani. Heal. Prod. 43, 1153-1159. https://doi.org/10.1007/s11250-0119816-2

Gholizadeh, M. \& Ghafouri-Kesbi, F., 2015. Estimation of genetic parameters for growth-related traits and evaluating the results of a 27-year selection program in Baluchi sheep. Small Rumin. Res. 130, 8-14. https://doi.org/10.1016/j.smallrumres.2015.07.032

Gholizadeh, M. \& Ghafouri-Kesbi, F., 2017. Genetic analysis of average daily gain in Baluchi sheep. Meta Gene. 13, 119-123. https://doi.org/10.1016/j.mgene.2017.05.009

Gizaw, S. \& Joshi, B., 2004. Estimates of genetic parameters of growth traits in Menz and Awassi x Menz crossbred sheep in Ethiopia. Indian J. Ani. Sci. 74, 864-867. 
Hussain, A., Akhtar, P., Ali, S., Javed, K., Younas, M., Shakoor, A. \& Waheed, U., 2014. Genetic analysis of postweaning growth traits of Thalli sheep under tropical conditions. Trop. Ani. Heal. Prod. 46, 1527-1531. https://doi.org/10.1007/s11250-014-0670-x

Iqbal, Z.M., Javed, K., Abdullah, M., Ahmad, N., Ali, A., Khalique, A., Aslam, N. \& Younas, U., 2014. Estimation of body weight from different morphometric measurements in Kajli lambs. The JAPS. 24, 700-703.

Javed, K., Iram, A., Abdullah, M., Sattar, M.A. \& Akhtar, M., 2013. Genetic trends for some productive traits of Lohi sheep in Pakistan. Pakistan J. Sci. 65, 492-495.

Kesbi, F.G. \& Tari, A.R., 2015. Relative growth rate in sheep: Heritability and relationship with absolute growth rate and body weight. Songklanakarin J. Sci. \& Tech. 37, 21-27.

Khan, S., Riaz, M.N., Ghaffar, A. \& Khan, M.F.U., 2012. Calpastatin (CAST) gene polymorphism and its association with average daily weight gain in Balkhi and Kajli sheep and Beetal goat breeds. Pakistan J. Zool. 44, 377-382.

Kruuk, L.E.B., Clutton-Brock, T.H., Slate, J., Pemberton, J.M., Brotherstone, S. \& Guinness, F.E., 2000. Heritability of fitness in a wild mammal population. Proc. Nat. Acad. Sci. 97, 698-703. https://doi.org/10.1073/pnas.97.2.698

Kuthu, Z.H., Javed, K., Babar, M.E., Sattar, A. \& Abdullah, M., 2013. Environmental effects on growth traits of Teddy goats. The JAPS. 23, 692-698.

Lalit, Z.S., Dalal, D.S., Dahiya, S.P., Patil, C.S. \& Dahiya, R., 2016. Genetic analysis of growth traits in Harnali sheep. Vet. World. 9, 128-132. http://doi.org/10.14202/vetworld.2016.128-132

Littell, R.C., Milliken, G.A., Stroup, W.W., Wolfinger, R.D. \& Oliver, S., 2006. SAS for mixed models. SAS. ISBN: 1590475003

London, J. \& Weniger, J., 1996. Investigations into traditionally managed Djallonké-sheep production in the humid and subhumid zones of Asante, Ghana V. Productivity indices. J. Ani. Breed. Genet. 113, 483-504. https://doi.org/10.1111/j.1439-0388.1996.tb00638.x

Lupi, T,M., Nogales, S., León, J.M., Barba, C. \& Delgado, J.V., 2015. Analysis of the non-genetic factors affecting the growth of Segureño sheep. Italian J. Ani. Sci. 14, 124-131. https://doi.org/10.4081/ijas.2015.3683

Mandal, A., Karunakaran, M., Sharma, D.K., Baneh, H. \& Rout, P.K., 2015. Variance components and genetic parameters of growth traits and Kleiber ratio in Muzaffarnagari sheep. Small Rumin. Res. 132, 79-85. https://doi.org/10.1016/j.smallrumres.2015.10.009

Matika, O., van Wyk, J.B., Erasmus, G.J. \& Baker, R.L., 2003. Genetic parameter estimates in Sabi sheep. Livest. Prod. Sci. 79, 17-28._https://doi.org/10.1016/S0301-6226(02)00129-X

Meyer, K., 2007. WOMBAT - A tool for mixed model analyses in quantitative genetics by restricted maximum likelihood (REML). J. Zhejiang Uni. Sci. 8, 815-821._https://doi.org/10.1631/jzus.2007.B0815

Miraei-Ashtiani, S.R., Seyedalian, S.A.R. \& Shahrbabak, M.M., 2007. Variance components and heritabilities for body weight traits in Sangsari sheep, using univariate and multivariate animal models. Small Rumin. Res. 73, 109-114. https://doi.org/10.1016/j.smallrumres.2006.12.002

Mohammadi, H., Shahrebabak, M.M., Shahrebabak, H.M., Bahrami, A. \& Dorostkar, M., 2013. Model comparisons and genetic parameter estimates of growth and the Kleiber ratio in Shal sheep. Arch. Ani. Breed. 56, 264-275. https://doi.org/10.7482/0003-9438-56-026

Mokhtari, M.S. \& Rashidi, A., 2010. Genetic trends estimation for body weights of Kermani sheep at different ages using multivariate animal models. Small Rumin. Res. 88, 23-26. https://doi.org/10.1016/j.smallrumres.2009.11.003

Mokhtari, M.S., Rashidi, A. \& Mohammadi, Y., 2008. Estimation of genetic parameters for post-weaning traits of Kermani sheep. Small Rumin. Res. 80, 22-27. https://doi.org/10.1016/j.smallrumres.2008.08.002

Nemutandani, K.R., Snyman, M.A., Olivier, W.J. \& Visser, C., 2018. Estimation of genetic parameters and comparison of breeding values for body weight with different models in a South African Merino stud. Small Rumin. Res. 169, 3441. https://doi.org/10.1016/j.smallrumres.2018.10.007

Patterson, H.D. \& Thompson, R., 1971. Recovery of inter-block information when block sizes are unequal. Biometrika. 58, 545-554. https://doi.org/10.1093/biomet/58.3.545

Petrovic, M.P., Muslic, D.R., Petrovic, V.C. \& Maksimovic, N., 2011. Influence of environmental factors on birth weight variability of indigenous Serbian breeds of sheep. African J. Biotech. 10, 4673-4676. http://doi.org/10.5897/AJB10.2189

Petrović, M.P., Petrović, C.V., Ružic-Muslić, D., Maksimović, N., Petrović, M.M., Ilić, Z. \& Stojković, J., 2015. Effect of genetic and environmental factors on the phenotype characteristics of lambs. Biotech. Ani. Husb. 31, $223-233$. $\mathrm{http} / /$ doi.org/10.2298/BAH1502223P

Qureshi, M.A., Babar, M.E. \& Ali, A., 2010. Environmental and genetic factors influencing performance traits of Kajli sheep in Pakistan. Pakistan J. Zool. 42, 339-343.

Qureshi, Z.I., Farid, A.H., Babar, M.E. \& Hossain, T., 2015. Leptin Gene Polymorphism in Lohi, Kajli and Spili Breeds of Sheep. Pakistan Vet. J. 35, 321-324.

Saddiqi, H.A., Nisa, M., Mukhtar, N., Shahzad, M.A., Jabbar, A. \& Sarwar, M., 2011. Documentation of physiological parameters and blood profile in newly born Kajli lambs. Asian-Austral. J. Ani. Sci. 24, 912-918. https://doi.org/10.5713/ajas.2011.10336

Sarghale, A.K. \& Arpanahi, R., 2014. Model comparisons and genetic parameter estimates of growth traits in Baluchi sheep. Slovak J. Ani. Sci. 47, 12-18.

Selvaggi, M., Pinto, F., Pesce-Delfino, A.R., Vicenti, A. \& Dario, C., 2011. Phenotypic and genetic parameters of preweaning growth traits in Gentile di Puglia lambs. World Acad. Sci. Engin. Tech. 78, 476-478.

Singh, H., Pannu, U., Narula, H.K., Chopra, A., Naharwara, V. \& Bhakar, S.K., 2016. Estimates of (co) variance components and genetic parameters of growth traits in Marwari sheep. J. Appl. Ani. Res. 44, $27-35$. https://doi.org/10.1080/09712119.2014.987291 
Snyman, M.A., 2012. Genetic analysis of body weight in South African Angora kids and young goats. S. Afri. J. Ani. Sci. 42, 146-155. http://dx.doi.org/10.4314/sajas.v42i2.7

Suleman, M., Khan, S.U., Riaz, M.N., Yousaf, M., Shah, A. \& Ishaq, R., 2012. Calpastatin (CAST) gene polymorphism in Kajli, Lohi and Thalli sheep breeds. African J. Biotech. 11, 10655-10660. http://dx.doi.org/10.5897/AJB11.2478

Sušić, V., Pavić, V., Mioč, B., Štoković, I. \& Kabalin, A.E., 2005. Seasonal variations in lamb birth weight and mortality. Veterinarski arhiv. 75, 375-381.

Tariq, M.M., Bajwa, M.A., Abbas, F., Waheed, A., Bokhari, F.A. \& Rafiq, M., 2010. Heritability of pre-weaning growth performance traits in Mengali sheep in (Balochistan) Pakistan. Intern. J. Biodivers. Conserv. 2, 284-288.

Thiruvenkadan, A.K., Karunanithi, K., Muralidharan, J. \& Babu, R.N., 2011. Genetic analysis of pre-weaning and postweaning growth traits of Mecheri sheep under dry land farming conditions. Asian-Austral. J. Ani. Sci. 24, 10411047. https://doi.org/10.5713/ajas.2011.10361

Tohidi, R., Ismailjami, Y. \& Javanmard, A., 2017. Analysis of the environmental factors affecting the growth traits of IranBlack sheep. Intern. J. Environ. Agricul. Biotech. 2, 159-164. http://dx.doi.org/10.22161/ijeab/2.1.21

Vatankhah, M. \& Salehi, S.A., 2010. Genetic and non-genetic factors affecting Lori-Bakhtiari ewe body weight and its relationship with productivity. Small Rumin. Res. 94, 98-102. https://doi.org/10.1016/j.smallrumres.2010.07.006

Wei, C., Wang, H., Liu, G., Wu, M., Cao, J., Liu, Z., Liu, R., Zhao, F., Zhang, L. \& Lu, J., 2015. Genome-wide analysis reveals population structure and selection in Chinese indigenous sheep breeds. Bmc Genomi. 16, 194. https://doi.org/10.1186/s12864-015-1384-9

Zung, A., Phillip, M., Chalew, S.A., Palese, T., Kowarski, A.A. \& Zadik, Z., 1999. Testosterone effect on growth and growth mediators of the GH-IGF-I axis in the liver and epiphyseal growth plate of juvenile rats. J. Molecul. Endocrinol. 23, 209-222. 